Article

\title{
Propagation Characteristics of Supercritical Carbon Dioxide Induced Fractures under True Tri-Axial Stresses
}

\author{
Yi Hu ${ }^{1}$, Feng Liu ${ }^{2,3, *}$, Yuqiang $\mathrm{Hu}^{4}$, Yong Kang ${ }^{2,3}$, Hao Chen ${ }^{2,3}$ and Jiawei Liu ${ }^{2,3}$ \\ 1 State Key Laboratory of Petroleum Resources and Prospecting, China University of Petroleum, \\ Beijing 102249, China; huxiaoyi@whu.edu.cn \\ 2 Hubei Key Laboratory of Waterjet Theory and New Technology, Wuhan University, Wuhan 430072, China; \\ kangyong@whu.edu.cn (Y.K.); chh@whu.edu.cn (H.C.); leo381644236@163.com (J.L.) \\ 3 School of Power and Mechanical Engineering, Wuhan University, Wuhan 430072, China \\ 4 Underground Gas Store Management Agency of Huabei Oilfield Company, Renqiu 062550, China; \\ cqk_hyq@petrochina.com.cn \\ * Correspondence: liufeng96@whu.edu.cn
}

Received: 19 September 2019; Accepted: 1 November 2019; Published: 6 November 2019

\begin{abstract}
Supercritical carbon dioxide $\left(\mathrm{SC}-\mathrm{CO}_{2}\right)$ fracturing is a non-aqueous fracturing technology, which has attracted considerable attention on exploiting shale gas. In this study, shale specimens and artificial sandstone specimens were used to conduct $\mathrm{SC}-\mathrm{CO}_{2}$ fracturing and water fracturing experiments to investigate the characteristics of $\mathrm{SC}-\mathrm{CO}_{2}$ induced fractures. An acoustic emission (AE) monitoring device was employed to monitor the $\mathrm{AE}$ energy release rate during the experiment. The experiment results indicate that the breakdown pressure of $\mathrm{SC}-\mathrm{CO}_{2}$ fracturing is lower than that of water fracturing under the same conditions, and the $\mathrm{AE}$ energy release rate of $\mathrm{SC}-\mathrm{CO}_{2}$ fracturing is 1-2 orders of magnitude higher than that of water fracturing. In artificial sandstone, which is homogeneous, the main fracture mainly propagates along the directions perpendicular to the minimum principal stress, no matter if using $\mathrm{SC}-\mathrm{CO}_{2}$ or water as the fracturing fluid, but in shale with weak structural planes, the propagation direction of the fracture is controlled by the combined effect of a weak structural plane and in-situ stress.
\end{abstract}

Keywords: $\mathrm{SC}-\mathrm{CO}_{2}$ fracturing; fracture propagation; acoustic emission; shale

\section{Introduction}

Shale gas is one of the unconventional resources which is stored in organic matter-rich shale formations. Technically recoverable shale gas reserves in China, estimated by the Energy Information Administration (EIA), are $36.1 \times 10^{12} \mathrm{~m}^{3}$ at standard temperature and mainly distributed in the Sichuan Basin, Tarim Basin, and Ordos Basin [1,2]. Due to the very small porosity ( $\%$ or less) and ultra-low permeability ( 0.1 to $0.0001 \mathrm{mD}$ or even less) of shale, it is difficult to exploit shale gas by conventional oil and gas exploitation methods. However, in the past 20 years, the breakthrough of horizontal drilling and hydraulic fracturing technology has triggered the "Shale Oil and Gas Revolution" all over the world [3]. Presently, hydraulic fracturing with multiple horizontal wells has been widely used in the exploitation of shale gas [4-6]. However, with the widespread use of hydraulic fracturing technology, its drawbacks also emerge. The hydraulic fracturing needs to consume a large amount of water and a typical shale gas well injects 2-4 million gallons of water into a deep shale reservoir, which is not conducive to the exploitation of shale gas reservoirs located in water shortage areas [7,8]. The flow-back water contaminated with secondary substances, which are added to the water to enhance fracture initiation and propagation, requires disposal $[3,9,10]$. The injection of water will alter the distribution of 
stresses and strains in the reservoir, which can induce low-magnitude earthquakes [3,11,12]. In addition to these disadvantages, the gas transport channels (interconnected pores and fractures in shale) can be blocked in shale reservoirs rich in clay minerals, due to the water swelling effect of clay such as montmorillonite, which reduces the gas recovery ratio [13,14].

SC- $\mathrm{CO}_{2}$ fracturing is a notable non-aqueous fracturing technology attracting great concern due to particular properties of SC- $\mathrm{CO}_{2}$ [15]. When temperature and pressure exceed $31.1^{\circ} \mathrm{C}$ and $7.38 \mathrm{MPa}$ respectively, $\mathrm{CO}_{2}$ goes into a supercritical state, and $\mathrm{SC}-\mathrm{CO}_{2}$ has unique properties, including a low viscosity similar to the gas state, a large density similar to the liquid state, low surface tension, and high diffusivity [16-18]. Using SC- $\mathrm{CO}_{2}$ as fracturing fluid can avoid problems caused by water, such as consuming large amounts of water and the swelling of clay, and offers several advantages over water. The key advantage of SC-CO $\mathrm{CO}_{2}$ fracturing is that $\mathrm{CO}_{2}$ can replace methane adsorbed in shale due to a higher capacity of $\mathrm{CO}_{2}$ adsorption in shale than methane, which is conducive to boost production $[19,20]$. In recent years, many researchers have investigated $\mathrm{SC}-\mathrm{CO}_{2}$ fracturing in unconventional reservoirs. A series of fracturing fluids with different viscosity and compressibility, such as water, gaseous $\mathrm{CO}_{2}$, liquid $\mathrm{CO}_{2}$ and oil, have been used for comparison experiments to highlight the superiority of SC-CO fracturing [21-24]. Various properties of rock samples, such as granite, shale, sandstone, artificial sandstone, and polymethyl methacrylate, have been used to investigate the initiation and propagation behavior of SC- $\mathrm{CO}_{2}$ induced fractures [24-29]. Various instruments, including acoustic emission (AE) monitoring systems, high speed cameras, electronic microscopes, three-dimensional scanners, and computed tomography scanning and profilometry, have been employed to monitor the process and analyze the results of $\mathrm{SC}-\mathrm{CO}_{2}$ fracturing [27-30].

Studying initiation and propagation of the fractures is helpful for evaluating the fracturing effect. The initiation and propagation behavior of fractures is affected by various factors, including engineering factors, such as fracturing fluid viscosity and injection rate, and geological factors, such as in-situ stress and discontinuities (bedding planes and natural fractures). The fracturing fluid viscosity affects the complexity and generation mode of the fracture created, and the fracture is complicated and is mainly caused by shear stress when fracturing fluid viscosity is low [22,24,31]. Injections rates that are too high or too low will reduce the complexity of fracture network [32,33]. The in-situ stress controls the breakdown pressure and propagation direction of fractures. The fracture is hard to be created by fracturing under a high in-situ stress field, and the hydraulic fractures tend to propagate along the directions perpendicular to the minimum principal stress $[34,35]$. The discontinuities, such as bedding planes and natural fractures, considerably affect the propagation and morphology of hydraulic fractures. When the fracture extends to the discontinuous interface, four cases may occur [36], as follows: (a) The hydraulic fracture penetrates through the discontinuous interface without diversion of fracture path or fluid flow dissipation; (b) the hydraulic fracture is arrested by the discontinuous interface and the width of the fracture increases and fluid is continuously stored in it; (c) the discontinuous interface opens and the fluid enters the discontinuous interface creating two branches; or (d) the hydraulic fracture offsets along the interface by a certain distance and the fracture propagates through the interface and re-initiates $[37,38]$. The cement strength of discontinuities and the dip angle of discontinuities, with respect to the stress field, are dominant factors that affect fracture propagation behavior when it encounters a discontinuous interface [39-41]. According to actual field observations, the natural fractures and rock properties have a great impact on fracture complexity [42,43].

This research used two types of rock samples, shale with beddings and joints and homogeneous artificial sandstone, to investigate the initiation and propagation characteristics of SC- $\mathrm{CO}_{2}$ induced fractures. An AE monitoring system was employed to observe the process of $\mathrm{SC}-\mathrm{CO}_{2}$ and water fracturing. The characteristics of $\mathrm{SC}-\mathrm{CO}_{2}$ fracturing were investigated through comparing with water fracturing, and propagation behaviors of fractures in shale were discussed by comparing with those in artificial sandstone. 


\section{Experimental Methodologies}

\subsection{Experimental Apparatuses}

The fracturing experiments were conducted by a true tri-axial fracturing system which could perform the $\mathrm{SC}-\mathrm{CO}_{2}$ fracturing experiment and the water fracturing experiment on a cubic specimen of $300 \times 300 \times 300 \mathrm{~mm}^{3}$ (see Figure 1). The system consists of SC-CO 2 generating device, a water injection device, a true tri-axial hydraulic loading device, and an AE detecting device.

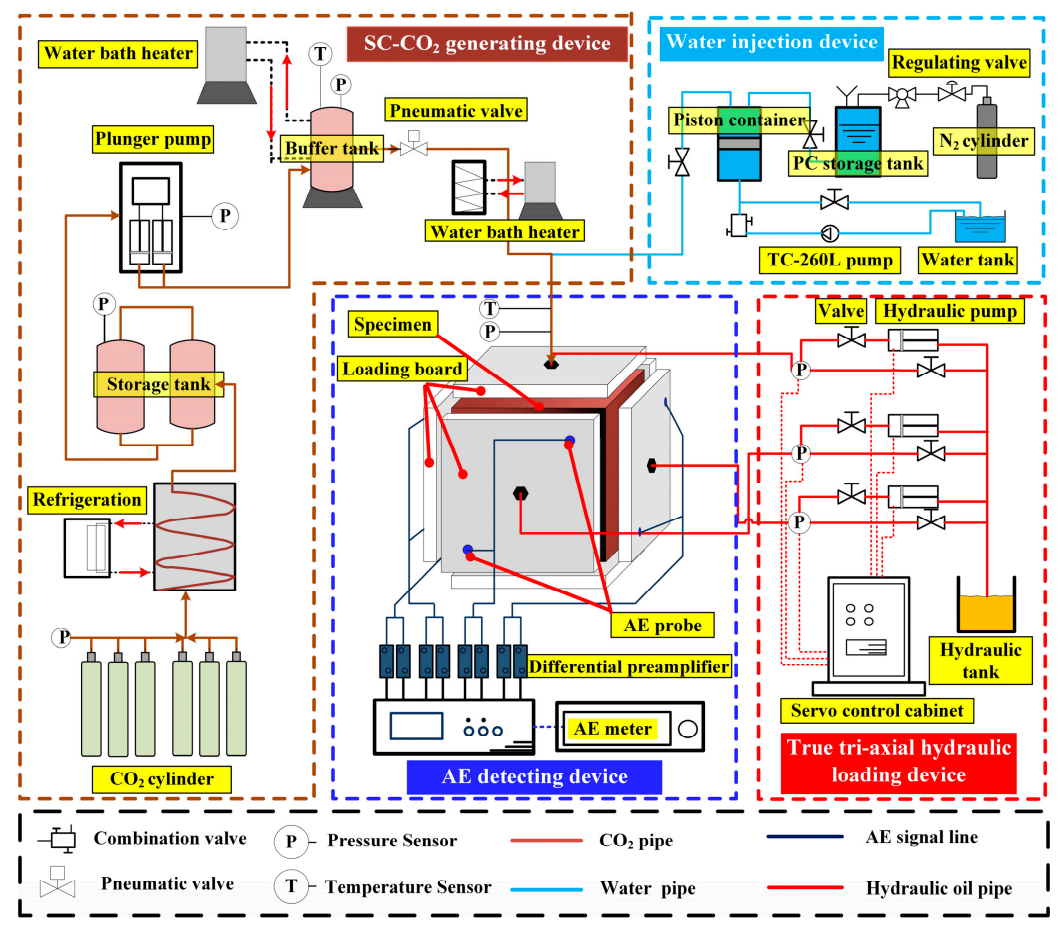

Figure 1. True tri-axial SC- $\mathrm{CO}_{2}$ fracturing and hydraulic fracturing system.

The SC- $\mathrm{CO}_{2}$ generating device can produce $\mathrm{SC}-\mathrm{CO}_{2}$ with temperatures from $35-100{ }^{\circ} \mathrm{C}$ and pressure from $10-80 \mathrm{MPa}$, and the forming process of $\mathrm{SC}-\mathrm{CO}_{2}$ is as follows: Firstly, the refrigeration converts high pressure $\mathrm{CO}_{2}$ gas from $\mathrm{CO}_{2}$ cylinder to liquid $\mathrm{CO}_{2}$ stored in a storage tank. Second, the triple plunger pump pressurizes the liquid $\mathrm{CO}_{2}$ to $10-80 \mathrm{MPa}$ and the high pressure liquid $\mathrm{CO}_{2}$ is stored in a buffer tank. Thirdly, the liquid $\mathrm{CO}_{2}$ stored in the buffer tank is heated by a water bath heater to $35-100{ }^{\circ} \mathrm{C}$, and the $\mathrm{CO}_{2}$ changes to a supercritical state when its temperature and pressure exceed $31.1{ }^{\circ} \mathrm{C}$ and 7.38 MPa, respectively. The water injection device can produce high pressure water with constant pressure ranging from $0-60 \mathrm{MPa}$ or a constant injection rate ranging from $0.01-60 \mathrm{~mL} / \mathrm{min}$ for water fracturing.

The true tri-axial hydraulic loading device can provide confining pressure to simulate in-situ stress for the experiment. The confining pressure can be applied along $\mathrm{X}-, \mathrm{Y}-$, and $\mathrm{Z}$ - directions independently by three hydraulic pumps, which are controlled by a servo control cabinet. The pressure is transmitted to the specimen by a loading board in each direction. The maximum pressure applied in each direction can reach up to $30 \mathrm{MPa}$.

The $\mathrm{AE}$ detecting device is composed of an $\mathrm{AE}$ meter, a differential preamplifier, and $\mathrm{AE}$ probes. The size of the AE probe is $\Phi 22 \times 36.8 \mathrm{~mm}$, and the detection frequency range is $15-70 \mathrm{KHz}$, with a resonant frequency of $40 \mathrm{KHz}$. Eight AE probes were place on four surfaces of the specimen, except the upper and lower surfaces, to monitor acoustic emission features in the experiment (see Figure 2a). 


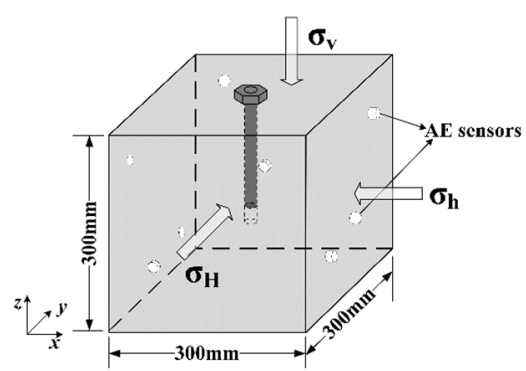

(a)

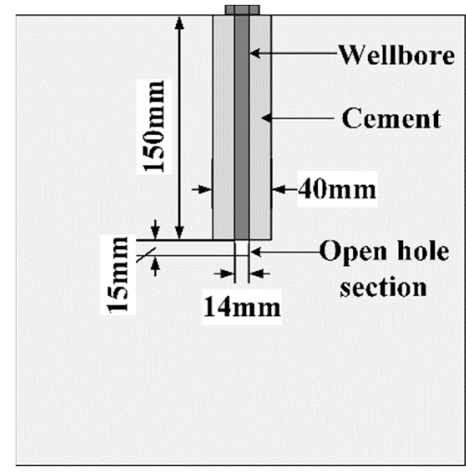

(b)

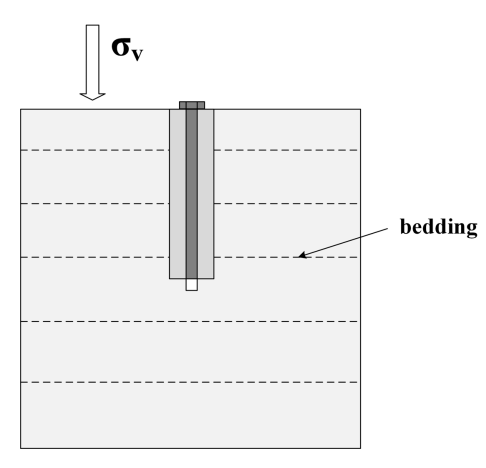

(c)

Figure 2. (a) AE sensor layout and loading schematic diagram; (b) sectional view of specimen schematic diagram; (c) the orientation of beddings in shale schematic diagram.

\subsection{Specimen Preparation}

Eight specimens $300 \times 300 \times 300 \mathrm{~mm}^{3}$ in size were used to conduct the experiment. Three of these specimens were shales and the rest were artificial sandstones. The shales were obtained from outcrops of the Changning Block in Sichuan Province, China, which belonged to black shale of a Longmaxi Formation, and beddings and joints existed in these shales. The artificial sandstones were made from a mixture of cement (P.C 32.5R), quartz sand (40-70 mesh), and water, with a mass ratio of 1:1:0.3, and the making process is as follows: The mixture was stirred evenly, and then it was poured into the a mold which could make cubic specimens $300 \times 300 \times 300 \mathrm{~mm}^{3}$ in size. After the mixture solidified, the rock specimen was taken out of the mold, and one artificial sandstone was made; then the artificial sandstones were maintained for 28 days at temperature of $25^{\circ} \mathrm{C}$. The mechanical properties of the shales and artificial sandstones were obtained by a uniaxial compressive strength (UCS) test and a splitting tensile strength (STS) test (Table 1).

Table 1. Physical and mechanical properties of the specimens.

\begin{tabular}{ccccc}
\hline Specimen & $\begin{array}{c}\text { Uniaxial } \\
\text { Compressive } \\
\text { Strength/MPa }\end{array}$ & $\begin{array}{c}\text { Tensile } \\
\text { Strength/MPa }\end{array}$ & $\begin{array}{c}\text { Elastic } \\
\text { Modulus/GPa }\end{array}$ & Poisson's Ratio \\
\hline Shale & 155.33 & 8.87 & 34.21 & 0.31 \\
\hline Artificial sandstone & 33.23 & 1.40 & 12.73 & 0.15 \\
\hline
\end{tabular}

In order to model the wellbore, two coaxial holes were drilled in the specimens (the first hole with diameter of $40 \mathrm{~mm}$ and depth of $150 \mathrm{~mm}$; the second hole with diameter of $14 \mathrm{~mm}$ and depth of $15 \mathrm{~mm}$ ), and then a stainless steel tube with a diameter of $14 \mathrm{~mm}$ was inserted into the center of the unset specimen and it was bond to the borehole wall by cement with a cementing length of $150 \mathrm{~mm}$, and an open hole section (OHS) measuring $15 \mathrm{~mm}$ was preserved (see Figure 2b). The orientation of the bedding in the shale was perpendicular to the direction of vertical stress $\left(\sigma_{v}\right)$ (see Figure $2 \mathrm{c}$ ).

\subsection{Experimental Procedure}

The specimen was put on the true tri-axial loading frame, and the eight AE sensors were connected to the data acquisition system were fitted inside the loaded boards and placed in direct contact with the specimen surfaces. After that, the stresses were independently loaded on the specimens by the true tri-axial hydraulic loading device along the $\mathrm{X}-, \mathrm{Y}-$, and $\mathrm{Z}$-directions in the Cartesian coordinate. The minimum horizontal stresses $\left(\sigma_{h}\right)$, maximum horizontal stresses $\left(\sigma_{H}\right)$, and vertical stress $\left(\sigma_{v}\right)$ were applied in the $X$-axis, $Y$-axis, and $Z$-axis directions, respectively (see Figure 2a). All experiments were conducted under the same stress states of $\sigma_{v}=9.8 \mathrm{MPa}, \sigma_{h}=8.5 \mathrm{MPa}, \sigma_{H}=10.5 \mathrm{MPa}$. After the 
confining pressure was loaded, the injection valve was opened and the fracturing fluid entered into the wellbore, and the acoustic signal was monitored by the AE detecting device. During the experiment, the injection valve was closed when the specimen was broken. After the experiment, all specimens were separated along the fracture traces on the surface to investigate the morphology of fracture plane. Table 2 provides the parameters used in the experiment. As for water fracturing, red ink (Bose, type $855)$ was mixed into the water in order to mark the crack induced.

Table 2. Experimental parameters and results.

\begin{tabular}{ccccc}
\hline $\begin{array}{c}\text { Specimen } \\
\text { No. }\end{array}$ & Specimen Type & Fracturing Fluid & $\begin{array}{c}\text { Breakdown } \\
\text { Pressure/MPa }\end{array}$ & Fracture Geometry \\
\hline SC-1 & Artificial sandstone & $\mathrm{SC}^{-} \mathrm{CO}_{2}$ & 12.14 & A main fracture with branches \\
SC-2 & Artificial sandstone & $\mathrm{SC}^{-\mathrm{CO}_{2}}$ & 15.16 & $\begin{array}{c}\text { A main fracture with branches } \\
\text { A main fracture with branches }\end{array}$ \\
SC-3 & Artificial sandstone & ${\mathrm{SC}-\mathrm{CO}_{2}}^{\text {Complex fracture network connected }}$ \\
SC-4 & Shale & 14.35 & 22.52 & $\begin{array}{c}\text { with multi-bedding planes and joint plane } \\
\text { Complex fracture network connected } \\
\text { with multi-bedding planes }\end{array}$ \\
SC-5 & SC- $-\mathrm{CO}_{2}$ & & 24.61 & A simple fracture \\
W-1 & Artificial sandstone & Water & 15.43 & A simple fracture \\
W-2 & Artificial sandstone & Water & 15.18 & A simple fracture \\
W-3 & Shale & Water & 26.60 & \\
\hline
\end{tabular}

\section{Experimental Results and Discussion}

Table 2 provides the fracturing results of the eight specimens. As several repetitive experiments conducted under the same experimental conditions showed similar trends, only the representative results of the four experiments (specimen SC-1, SC-5, W-2, and W-3) are presented in this section.

\subsection{Fluid Pressure During Fracturing}

The fluid pressure at the well head, monitored by a pressure transducer during the experiment, is shown in Figure 3. The fluid pressure-time curve can be divided into four stages, as follows: Fluid injection and pressure rise stage (A-B), specimen rupture stage $(B-C)$, fracture propagation stage $(\mathrm{C}-\mathrm{D})$, and stop injection and pressure decay stage (D-E). There are some differences between the fluid pressure-time curve of $\mathrm{SC}-\mathrm{CO}_{2}$ fracturing and water fracturing.

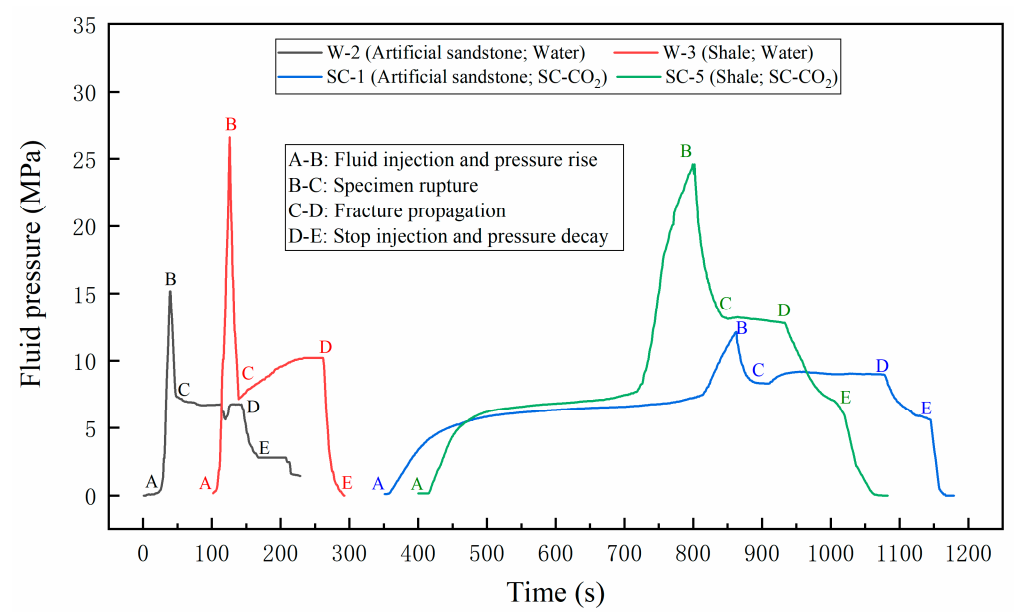

Figure 3. Fluid pressure-time curves during fracturing.

As for water fracturing, when the control valve was opened, the water entered into the well quickly, with a rapid increase of fluid pressure (A-B). When the fluid pressure reached the breakdown pressure of the specimens, the fracture occurred, and more space was created for the water to store, which led to a rapid decrease of fluid pressure (B-C). The fluid pressure decreased by $73.2 \%$ in $\mathrm{W}-3$, 
and the decrease degree is larger than that in $\mathrm{W}-2$, in which the fluid pressure decreased by $53.9 \%$. This means that more fracture volume was created in W-3 (shale) at the specimen rupture stage due to the existence of bedding planes in the shale. At the fracture propagation stage (C-D), the fluid pressure changed slowly, and the fluid flow in and out gradually reached a balanced state. When water appeared on the outside of specimen, the control valve was closed, and the fluid pressure dropped rapidly (D-E).

The fluid pressure-time curve of SC-CO $\mathrm{CO}_{2}$ fracturing was different from water fracturing at the fluid injection and pressure rise stage. When the control valve was opened, the $\mathrm{SC}-\mathrm{CO}_{2}$ entered into the well and changed to a gas at the first time under the low pressure, and the fluid pressure rose rapidly at first, which was followed by a slow rise in fluid pressure due to the complex phase transition process of $\mathrm{CO}_{2}$ from gaseous to supercritical. The fluid pressure increased rapidly again when the $\mathrm{CO}_{2}$ in the well was supercritical (A-B). At the specimen rupture stage (B-C), the slope of the pressure curve and the pressure decrease degrees (the pressure decreased by $31.6 \%$ in $\mathrm{SC}-1$ and the pressure decreased by $46.7 \%$ in SC-5) for SC- $\mathrm{CO}_{2}$ fracturing were smaller than that in water fracturing under the same conditions. As a consequence of the high compressibility of $\mathrm{SC}-\mathrm{CO}_{2}$, when the pressure dropped, the $\mathrm{SC}-\mathrm{CO}_{2}$ expanded to retard the decrease of pressure. When the fracture extended to the surface of specimen, a jet phenomenon caused by the $\mathrm{CO}_{2}$ escaping from the rock and transitioning from supercritical to gas occurred, and the control valve was turned off.

\subsection{Comparison of Breakdown Pressure}

The breakdown pressure is the peak value of the fluid pressure, and the breakdown pressure data of the eight specimens are listed in Table 2. The average breakdown pressure of artificial sandstone fractured by SC-CO $\mathrm{CO}_{2}$ is $13.88 \mathrm{MPa}$, which is almost $10 \%$ lower than the average breakdown pressure of artificial sandstone fractured by water. The average breakdown pressure of shale fractured by $\mathrm{SC}-\mathrm{CO}_{2}$ is $23.57 \mathrm{MPa}$, and the breakdown pressure of shale fractured by water under the same condition is $26.60 \mathrm{MPa}$. It is clear that whether using shale or artificial sandstone to conduct fracturing experiment, the breakdown pressure of experiment using $\mathrm{SC}-\mathrm{CO}_{2}$ as fracturing fluid is lower than that using water as fracturing fluid, which is consistent with the studies of Zou et al. [26], who used layered tight sandstone to conduct fracturing experiments, and Zhang et al. [22], who used shale to conduct experiments.

Since diffusivity of SC- $\mathrm{CO}_{2}$ is greater than that of water in the same porous medium, the amount of $\mathrm{SC}-\mathrm{CO}_{2}$ penetrating into the area around the open hole section is larger than that of water at the pressure rise stage (A-B), which leads the pore fluid pressure around the open hole section during $\mathrm{SC}-\mathrm{CO}_{2}$ fracturing to be higher than the pore fluid pressure around the open hole section during water fracturing. According to the study of Zhang et al. [22], the high pore fluid pressure caused by SC-CO penetration reduces the breakdown pressure.

\subsection{Acoustic Emission Characteristics During Fracturing}

In this section, AE energy, which is residual elastic energy released by an acoustic emission source (rupture section of the specimen) and measured from surface of the material after propagation attenuation, and $\mathrm{AE}$ cumulative energy, which can reflect total elastic energy released during fracturing process, are used to investigate the fracturing initiation and propagation process in $\mathrm{SC}-\mathrm{CO}_{2}$ fracturing and water fracturing. The AE energy is mainly affected by three factors during fracturing, as follows: Intensity of the AE source, propagation medium of the elastic wave, and fracturing fluid [13].

The AE probe converts elastic waves generated by acoustic emission sources into electrical signals, and the energy of an electrical signal is a proportional to the square of the voltage, so the AE energy generated by each event can be calculated using the following formula [44]:

$$
E_{i}=\int_{t_{0}}^{t_{1}} V_{i}(t)^{2} d t
$$


where the subscript $i$ is the channel number of the recorded voltage transient $V(t)$ and $t_{0}$ and $t_{1}$ are the start and end of the voltage transient record, respectively. The AE energy value is summed over all eight channels to get the total energy measured for each event.

The AE energy and cumulative energy varying with time during $\mathrm{SC}-\mathrm{CO}_{2}$ fracturing and water fracturing are shown in Figure 4. The AE energy release rates of the water fracturing had the same features. The AE energy signal was severe (energy surge), in the tens of seconds, before and after the breakdown point of the specimen. At the fracture propagation stage, the AE energy signal was weak at first and it became strong again when the fractures extended to the surface of the specimen. The AE energy signal still existed after stopping the fluid injection (shut-in) due to the fracture closure. During the process of $\mathrm{SC}-\mathrm{CO}_{2}$ fracturing, the AE energy release rate was intense (energy surge) at the specimen rupture stage. The AE energy signal was relatively severe during the whole stage, which was different from water fracturing in that the $\mathrm{AE}$ energy signal was weak at the early stage of fracture propagation. After stopping fluid injection, the AE energy signal still existed, which was similar to water fracturing.



(a) W-2: Artificial sandstone in water fracturing

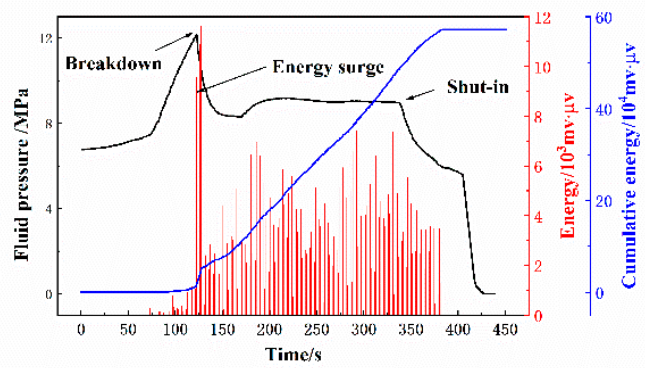

(c) SC-1: Artificial sandstone in $\mathrm{SC}-\mathrm{CO}_{2}$ fracturing

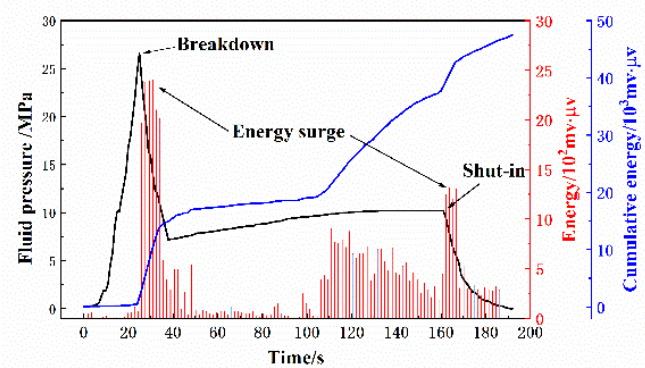

(b) W-3: Shale in water fracturing

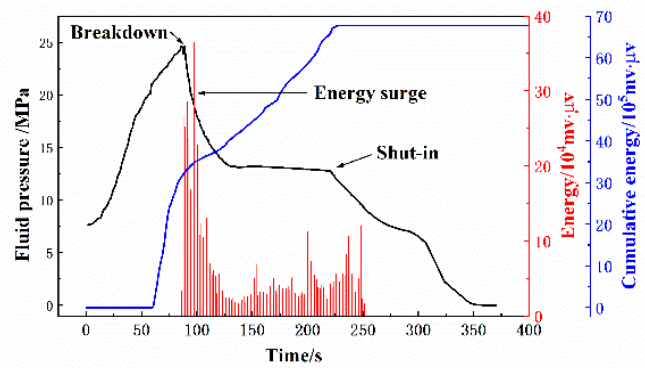

(d) SC-5: Shale in $\mathrm{SC}-\mathrm{CO}_{2}$ fracturing

Figure 4. Injection pressure, $\mathrm{AE}$ energy, and cumulative energy versus time in water and $\mathrm{SC}-\mathrm{CO}_{2}$ fracturing.

Comparing the AE energy release rate between $\mathrm{SC}-\mathrm{CO}_{2}$ fracturing and water fracturing, the $\mathrm{AE}$ energy release rate of $\mathrm{SC}-\mathrm{CO}_{2}$ fracturing was 1-2 orders of magnitude higher than that of water fracturing, signifying that more energy can be converted into kinetic energy to promote fracture growth [45]. The AE energy release rates and AE cumulative energy in shale (W-3 Figure $4 \mathrm{~b}$ ) and artificial sandstone (W-2 Figure 4a) using water as fracturing fluid were of the same magnitude, and there was only a simple fracture in W-2 (Figure 5b) and W-3 (Figure 6b). However, the AE energy release rate and $\mathrm{AE}$ cumulative energy in shale (SC-5 Figure 4d) using $\mathrm{SC}-\mathrm{CO}_{2}$ fracturing was one order of magnitude higher than that in artificial sandstone (SC-1 Figure 4c), which meant more ruptures were created in shale. Through the observation of fracture morphology in SC-5 (Figure 6a) and in SC-1 (Figure 5a), that more ruptures were created in shale was because $\mathrm{SC}-\mathrm{CO}_{2}$ could wreck the weak planes in shale and the artificial sandstone was homogeneous without a weak plane. In conclusion, AE energy release rate and $\mathrm{AE}$ cumulative energy can reflect the complexity of the fracture created, and more $\mathrm{AE}$ energy releases during $\mathrm{SC}-\mathrm{CO}_{2}$ fracturing compared to water fracturing under the same conditions. 

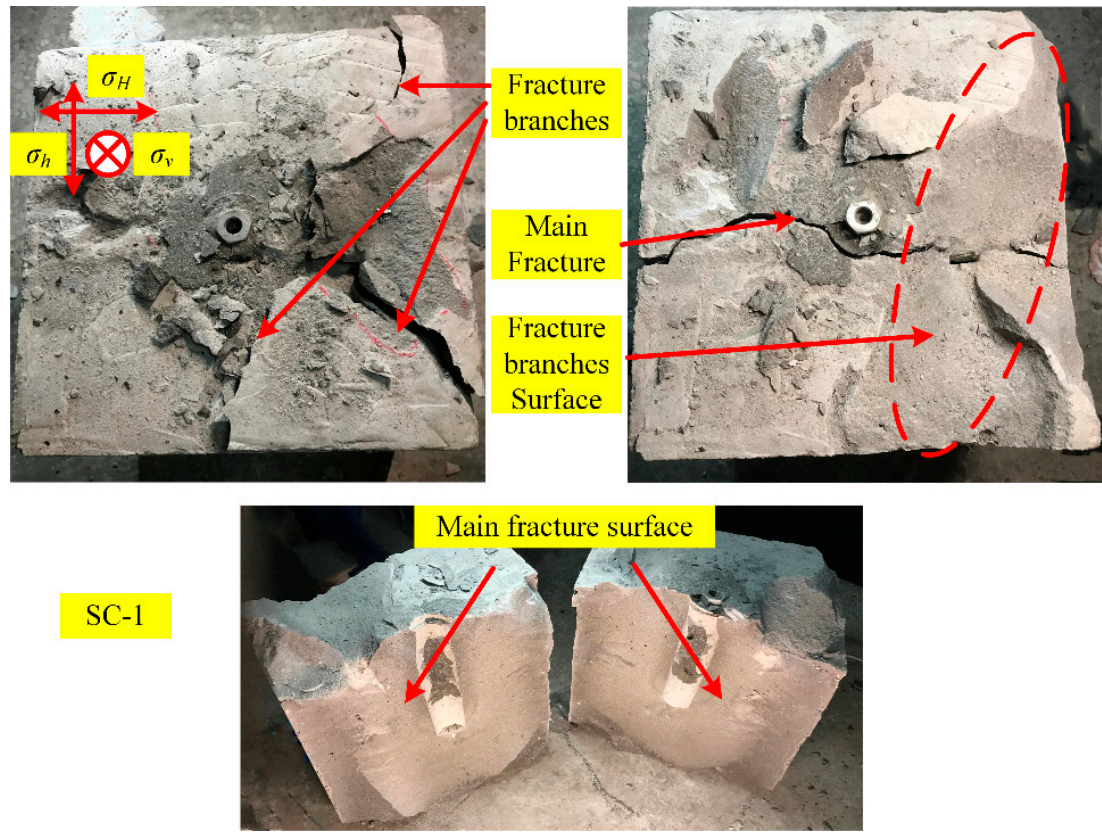

(a)
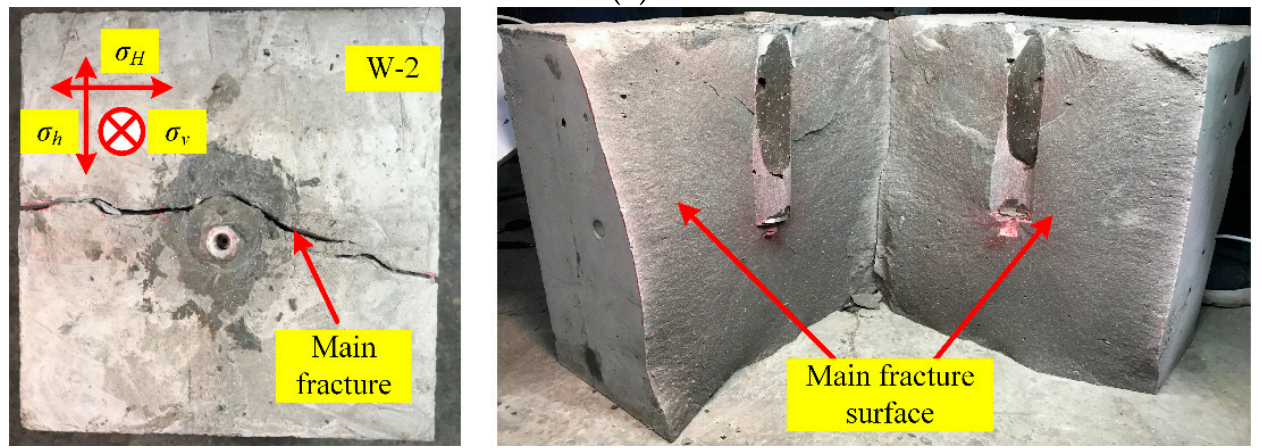

(b)

Figure 5. Comparison of fracture propagation and morphology in artificial sandstone between $\mathrm{SC}-\mathrm{CO}_{2}$ induced fractures and water induced fractures. (a) SC-1: Artificial sandstone fractured by $\mathrm{SC}_{-} \mathrm{CO}_{2}$. The upper broken rocks are being removed from the top left to right images; (b) W-2: Artificial sandstone fractured by water.

\subsection{Fracture Propagation and Morphology}

The spatial morphology of fractures induced by $\mathrm{SC}-\mathrm{CO}_{2}$ or water in artificial sandstone and shales are shown in Figures 5 and 6, respectively. As shown in Figure 5a, the artificial sandstone fractured by $\mathrm{SC}-\mathrm{CO}_{2}$ had a main fracture with multi-fracture branches, and the main fracture initiated from the open hole section and extended to the specimen surface along approximately perpendicular directions to the minimum principal stress $\left(\sigma_{h}\right)$. Through the observation of fracture morphology inside the specimen, the fracture branch surfaces were found to be oblique to the main fracture surface at a large angle, and were far from the open hole section, which meant that the fracture branches were caused by main fracture bifurcation when it extended to the specimen surface. As shown in Figure $5 b$, the artificial sandstone fractured by water only had a simple hydraulic fracture, and the fracture also initiated from the open hole section and extended to the specimen surface along directions approximately perpendicular to the minimum principal stress $\left(\sigma_{h}\right)$. The morphology of the fracture surface was flat, and there was no obvious fracture bifurcation phenomenon in the specimen. In conclusion, the $\mathrm{SC}-\mathrm{CO}_{2}$ fracturing can produce more complicated fractures than conventional water fracturing, and the main fracture mainly propagates along directions perpendicular to the minimum principal stress no matter if using $\mathrm{SC}-\mathrm{CO}_{2}$ or water as a fracturing fluid when using artificial sandstone as a fracturing material. 

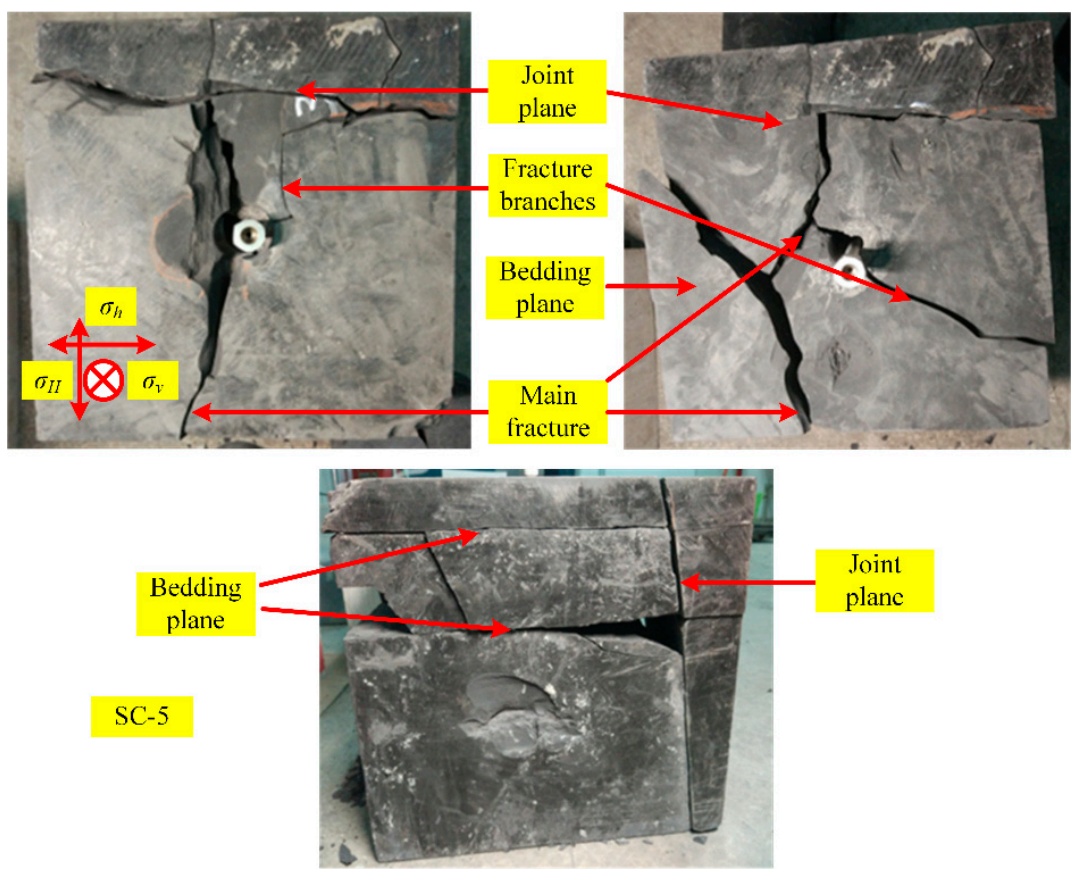

(a)
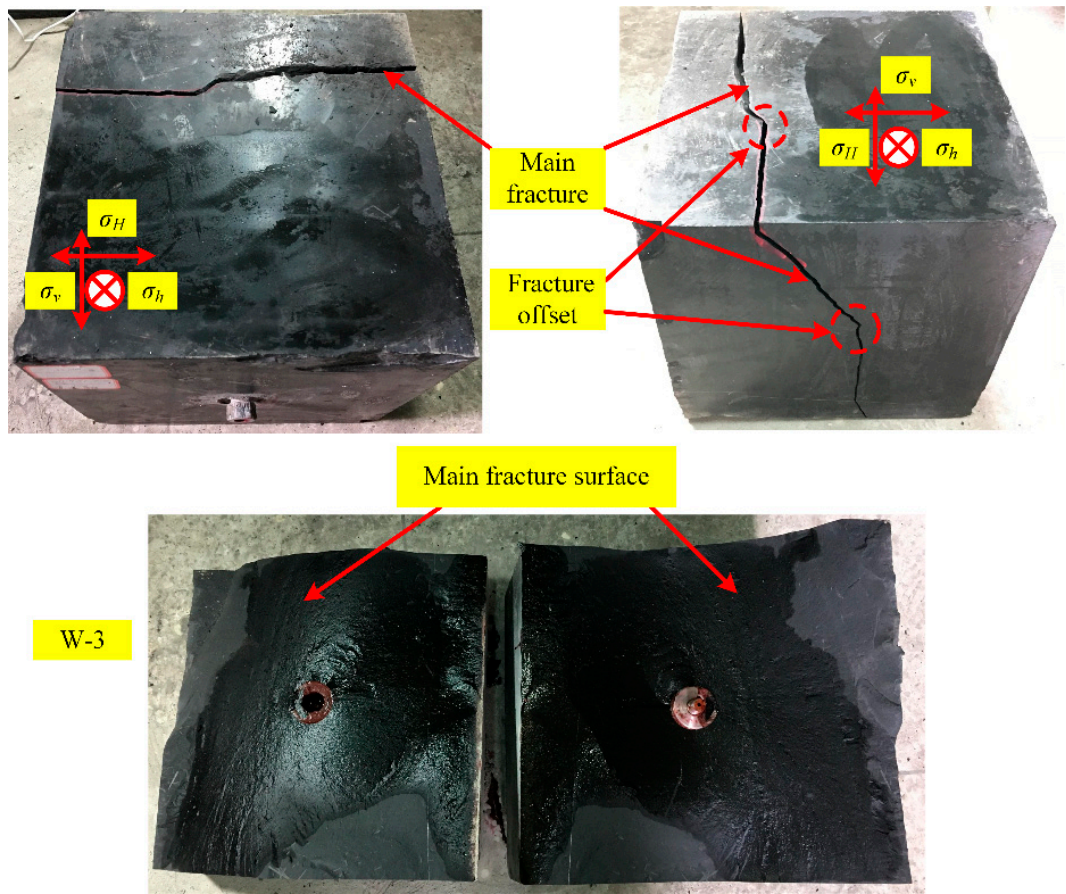

(b)

Figure 6. Comparison of fractures propagation and morphology in shale between $\mathrm{SC}-\mathrm{CO}_{2}$ induced fractures and water induced fractures. (a) SC-5: Shale fractured by SC- $\mathrm{CO}_{2}$. The upper broken rocks were removed from the top left to right images; (b) W-3: Shale fractured by water.

The fracture morphology in shale is different from that in artificial sandstone. As shown in Figure $6 \mathrm{a}$, the shale fractured by SC- $\mathrm{CO}_{2}$ has complex fracture networks connected with multi-bedding planes and joint planes. Observing from the upper surface of the specimen, a main fracture initiated from the open hole section and extended along directions approximately perpendicular to the minimum principal stress $\left(\sigma_{h}\right)$, connecting with a fracture propagated along the joint plane and a fracture branch initiated from the well connecting with the joint plane. Viewing from the side surface, two fractures 
propagated along the bedding plane and connected with the joint plane, and a complicated fracture network formed. Taking off the rocks on the top of bedding plane (Figure 5 top right-upper rocks removed), the fractures were more complicated below the bedding plane. As shown in Figure 6b, the shale fractured by water only had a single horizontal fracture, and no vertical fracture occurs. Since bedding plane is well developed in shale, and in the meantime, weak cementing bedding plane occurs at the open hole section, the fracture is prone to extend along horizontal bedding plane. Fracture diversion phenomenon occurred in this sample, and the direction of fracture extension diverted to the direction perpendicular to the minimum principal stress $\left(\sigma_{h}\right)$ due to influence of in-situ stresses. In fact, the fracture propagation and morphology are significantly influenced by a weak structural plane (bedding planes, joint planes, and natural fractures) and in-situ stresses [27,35,46,47], and the fracture propagation direction is controlled by combined effect of a weak structural plane and in-situ stresses. Comparing fracture propagation and morphology in SC-5 and W-3, the fractures created by $\mathrm{SC}-\mathrm{CO}_{2}$ fracturing were more complicated than fractures created by water fracturing, and the $\mathrm{SC}-\mathrm{CO}_{2}$ induced fractures were prone to connect with the weak structural plane (bedding plane and joint plane) to form a more complex fracture network than water induced fractures due to the low viscosity and high diffusivity of SC- $\mathrm{CO}_{2}$, which is consistent with the experimental study of Zhang et al. [22].

Comparing fractures in artificial sandstone (Figure 5a) and shale (Figure $6 \mathrm{~b}$ ) induced by $\mathrm{SC}-\mathrm{CO}_{2}$, the existing of the bedding plane and the joint plane increases the complexity of fractures and is conducive to the formation of complex fracture network in shale by $\mathrm{SC}-\mathrm{CO}_{2}$ fracturing. As for fractures created by water in artificial sandstone (Figure $5 b$ ) and shale (Figure $6 b$ ), the fractures were simple in the two specimens, but the fracture in artificial sandstone which propagated along the direction approximately perpendicular to the minimum principal stress $\left(\sigma_{h}\right)$ was vertical. The fracture in shale, which is dominated by the effect of the bedding plane, was mainly horizontal with obvious diversion phenomenon caused by in-situ stress. It is clear that a weak structural plane and in-situ stress compete for the dominance of the propagation direction of fractures [21].

\section{Conclusions}

In this study, a series of SC- $\mathrm{CO}_{2}$ fracturing and water fracturing experiments were conducted on cubic shale with bedding planes and homogeneous artificial sandstone and combined with $\mathrm{AE}$ monitoring to investigate the characteristics of $\mathrm{SC}-\mathrm{CO}_{2}$ fracturing. Based on this experiment, the following conclusions can be drawn:

1. The fluid pressure-time curve of $\mathrm{SC}-\mathrm{CO}_{2}$ fracturing is different from water fracturing. The pressure rise stage of SC- $\mathrm{CO}_{2}$ fracturing takes $7-9$ min due to the complex phase transition process of $\mathrm{CO}_{2}$ in this stage, and the pressure rise stage of water fracturing only takes 1-2 min. At the specimen rupture stage and pressure decay stage, the pressure drop process of $\mathrm{SC}-\mathrm{CO}_{2}$ is relatively flat compared with water fracturing due to the high compressibility of $\mathrm{SC}-\mathrm{CO}_{2}$.

2. Under the same in-situ stress condition, the breakdown pressure of $\mathrm{SC}-\mathrm{CO}_{2}$ fracturing is about $10 \%$ lower than that of water fracturing no matter if using shale or artificial sandstone as fracturing materials, because the percolation effect of $\mathrm{SC}-\mathrm{CO}_{2}$ can greatly increase pore pressure, which leads to the decrease in breakdown pressure.

3. The AE energy surge phenomena mainly occur at the specimen rupture stage due to the severe rupture of the specimens. The $\mathrm{AE}$ energy release rate of $\mathrm{SC}-\mathrm{CO}_{2}$ fracturing is $1-2$ orders of magnitude higher than that of water fracturing, signifying that more energy can be converted into kinetic energy to promote fracture growth.

4. By observing the fracture morphology in shale and artificial sandstone fracturing by $\mathrm{SC}-\mathrm{CO}_{2}$ and water, the main fracture mainly propagates along the directions perpendicular to the minimum principal stress in artificial sandstone, which is homogeneous no matter if using SC-CO as fracturing fluid; but in shale, the weak structural plane and in-situ stresses compete for the dominance of the propagation direction of the fractures. 
Author Contributions: Y.H. (Yi Hu), F.L., and Y.K. conceived and designed the schemes; H.C. and J.L. performed the experiments; Y.H. (Yi Hu), F.L., and Y.H. (Yuqiang Hu) analyzed the data; Y.H. (Yi Hu) and F.L. wrote the paper.

Funding: This work is supported by China Postdoctoral Science Foundation Founded Project (No. 2019M650963), National Natural Science Foundation of China (No. 51804318) and National Key Basic Research and Development Program of China (No. 2014CB239203).

Conflicts of Interest: The authors declare no conflict of interest.

\section{References}

1. Wang, X.; Wang, T. The Shale Gas Potential of China. In SPE Production and Operations Symposium; Society of Petroleum Engineers: Oklahoma City, OK, USA, 2011; p. 7.

2. Dong, D.; Guan, Q.; Wang, S.; Huang, J.; Wang, Y.; Zhang, C.J.E.E. Exploitation, Shale gas in China: Reality and dream. Energy Explor. Exploit. 2015, 33, 397-418. [CrossRef]

3. Wang, Q.; Chen, X.; Jha, A.N.; Rogers, H. Natural gas from shale formation-The evolution, evidences and challenges of shale gas revolution in United States. Renew. Sustain. Energy Rev. 2014, 30, 1-28. [CrossRef]

4. Fisher, M.K.; Warpinski, N.R. Hydraulic-Fracture-Height Growth: Real Data. SPE-145949-PA 2012, 27, 8-19. [CrossRef]

5. Eberhardt, E.; Amini, A. Hydraulic Fracturing. In Encyclopedia of Engineering Geology; Bobrowsky, P.T., Marker, B., Eds.; Springer International Publishing: Cham, Switzerland, 2018; pp. 489-495.

6. Liang, B.; Jiang, H.; Li, J.; Gong, C.; Jiang, R.; Pei, Y.; Wei, S. Flow in multi-scale discrete fracture networks with stress sensitivity. J. Nat. Gas Sci. Eng. 2016, 35, 851-859. [CrossRef]

7. Scanlon, B.R.; Reedy, R.C.; Nicot, J.P. Comparison of water use for hydraulic fracturing for unconventional oil and gas versus conventional oil. Environ. Sci. Technol. 2014, 48, 12386-12393. [CrossRef] [PubMed]

8. Hu, Y.; Kang, Y.; Wang, X.; Li, X.; Huang, M.; Zhang, M. Experimental and theoretical analysis of a supercritical carbon dioxide jet on wellbore temperature and pressure. J. Nat. Gas Sci. Eng. 2016, 36, 108-116. [CrossRef]

9. Vengosh, A.; Warner, N.; Jackson, R.; Darrah, T. The Effects of Shale Gas Exploration and Hydraulic Fracturing on the Quality of Water Resources in the United States. Procedia Earth Planet. Sci. 2013, 7, 863-866. [CrossRef]

10. Jackson, R.E.; Gorody, A.W.; Mayer, B.; Roy, J.W.; Ryan, M.C.; Van Stempvoort, D.R. Groundwater protection and unconventional gas extraction: The critical need for field-based hydrogeological research. Groundwater 2013, 51, 488-510. [CrossRef]

11. Pearson, C. The relationship between microseismicity and high pore pressures during hydraulic stimulation experiments in low permeability granitic rocks. J. Geophys. Res. Solid Earth 1981, 86, 7855-7864. [CrossRef]

12. Elsworth, D.; Spiers, C.J.; Niemeijer, A.R.J.S. Understanding induced seismicity. Science 2016, 354, $1380-1381$. [CrossRef]

13. Zhao, X.L.; Huang, B.X.; Xu, J. Experimental investigation on the characteristics of fractures initiation and propagation for gas fracturing by using air as fracturing fluid under true triaxial stresses. Fuel 2019, 236, 1496-1504. [CrossRef]

14. Lyu, Q.; Ranjith, P.G.; Long, X.; Kang, Y.; Huang, M. A review of shale swelling by water adsorption. J. Nat. Gas Sci. Eng. 2015, 27, 1421-1431. [CrossRef]

15. Middleton, R.S.; Carey, J.W.; Currier, R.P.; Hyman, J.D.; Kang, Q.J.; Karra, S.; Jimenez-Martinez, J.; Porter, M.L.; Viswanathan, H.S. Shale gas and non-aqueous fracturing fluids: Opportunities and challenges for supercritical $\mathrm{CO}_{2}$. Appl. Energy 2015, 147, 500-509. [CrossRef]

16. Middleton, R.; Viswanathan, H.; Currier, R.; Gupta, R. $\mathrm{CO}_{2}$ as a fracturing fluid: Potential for commercial-scale shale gas production and $\mathrm{CO}_{2}$ sequestration. Energy Procedia 2014, 63, 7780-7784. [CrossRef]

17. Gupta, A.P.; Gupta, A.; Langlinais, J. Feasibility of Supercritical Carbon Dioxide as a Drilling Fluid for Deep Underbalanced Drilling Operation. In SPE Annual Technical Conference and Exhibition; Society of Petroleum Engineers: Dallas, TX, USA, 2005; p. 10.

18. Hu, Y.; Liu, Y.W.; Cai, C.; Kang, Y.; Wang, X.C.; Huang, M.; Chen, F. Fracture Initiation of an Inhomogeneous Shale Rock under a Pressurized Supercritical $\mathrm{CO}_{2}$ Jet. Appl. Sci. 2017, 7, 1093. [CrossRef]

19. Heller, R.; Zoback, M. Adsorption of methane and carbon dioxide on gas shale and pure mineral samples. J. Unconv. Oil Gas Resour. 2014, 8, 14-24. [CrossRef]

20. Weniger, P.; Kalkreuth, W.; Busch, A.; Krooss, B.M. High-pressure methane and carbon dioxide sorption on coal and shale samples from the Paraná Basin, Brazil. Int. J. Coal Geol. 2010, 84, 190-205. [CrossRef] 


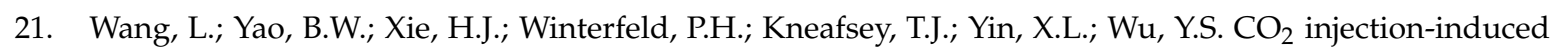
fracturing in naturally fractured shale rocks. Energy 2017, 139, 1094-1110. [CrossRef]

22. Zhang, X.W.; Lu, Y.Y.; Tang, J.R.; Zhou, Z.; Liao, Y. Experimental study on fracture initiation and propagation in shale using supercritical carbon dioxide fracturing. Fuel 2017, 190, 370-378. [CrossRef]

23. Ishida, T.; Aoyagi, K.; Niwa, T.; Chen, Y.Q.; Murata, S.; Chen, Q.; Nakayama, Y. Acoustic emission monitoring of hydraulic fracturing laboratory experiment with supercritical and liquid $\mathrm{CO}_{2}$. Geophys. Res. Lett. 2012, 39, 16309. [CrossRef]

24. Chen, Y.Q.; Nagaya, Y.; Ishida, T. Observations of Fractures Induced by Hydraulic Fracturing in Anisotropic Granite. Rock Mech. Rock Eng. 2015, 48, 1455-1461. [CrossRef]

25. Ning, L.; Zhang, S.; Zou, Y.; Ma, X.; Shan, W.; Zhang, Y. Experimental Analysis of Hydraulic Fracture Growth and Acoustic Emission Response in a Layered Formation. Rock Mech. Rock Eng. 2018, 51, 1047-1062. [CrossRef]

26. Zou, Y.S.; Li, N.; Ma, X.F.; Zhang, S.C.; Li, S. Experimental study on the growth behavior of supercritical $\mathrm{CO}_{2}$-induced fractures in a layered tight sandstone formation. J. Nat. Gas Sci. Eng. 2018, 49, 145-156. [CrossRef]

27. Zhao, Z.H.; Li, X.; He, J.M.; Mao, T.Q.; Zheng, B.; Li, G.F. A laboratory investigation of fracture propagation induced by supercritical carbon dioxide fracturing in continental shale with interbeds. J. Pet. Sci. Eng. 2018, 166, 739-746. [CrossRef]

28. Chen, H.; Hu, Y.; Kang, Y.; Cai, C.; Liu, J.; Liu, Y. Fracture initiation and propagation under different perforation orientation angles in supercritical $\mathrm{CO}_{2}$ fracturing. J. Pet. Sci. Eng. 2019, 183, 106403. [CrossRef]

29. Zhou, D.W.; Zhang, G.Q.; Zhao, P.Y.; Wang, Y.Y.; Xu, S.F. Effects of post-instability induced by supercritical $\mathrm{CO}_{2}$ phase change on fracture dynamic propagation. J. Pet. Sci. Eng. 2018, 162, 358-366. [CrossRef]

30. Jia, Y.Z.; Lu, Y.Y.; Elsworth, D.; Fang, Y.; Tang, J.R. Surface characteristics and permeability enhancement of shale fractures due to water and supercritical carbon dioxide fracturing. J. Pet. Sci. Eng. 2018, 165, $284-297$. [CrossRef]

31. Bennour, Z.; Watanabe, S.; Chen, Y.; Ishida, T.; Akai, T. Evaluation of stimulated reservoir volume in laboratory hydraulic fracturing with oil, water and liquid carbon dioxide under microscopy using the fluorescence method. Geomech. Geophys. Geo-Energy Geo-Resour. 2017, 4, 39-50. [CrossRef]

32. Deng, B.Z.; Yin, G.Z.; Zhang, D.M.; Li, M.H.; Liu, Y.B.; Lu, J. Experimental investigation of fracture propagation induced by carbon dioxide and water in coal seam reservoirs. Powder Technol. 2018, 338, 847-856. [CrossRef]

33. Tan, P.; Jin, Y.; Han, K.; Hou, B.; Chen, M.; Guo, X.F.; Gao, J. Analysis of hydraulic fracture initiation and vertical propagation behavior in laminated shale formation. Fuel 2017, 206, 482-493. [CrossRef]

34. Hubbert, M.K.; Willis, D.G. Mechanics Of Hydraulic Fracturing. In Petroleum Branch Fall Meeting in Los Angeles; Society of Petroleum Engineers: Angeles, CA, USA, 1957; p. 16.

35. Zhang, Y.S.; Zhang, J.C.; Yuan, B.; Yin, S.X. In-situ stresses controlling hydraulic fracture propagation and fracture breakdown pressure. J. Pet. Sci. Eng. 2018, 164, 164-173. [CrossRef]

36. Zhang, X.; Jeffrey, R.G.; Thiercelin, M. Deflection and propagation of fluid-driven fractures at frictional bedding interfaces: A numerical investigation. J. Struct. Geol. 2007, 29, 396-410. [CrossRef]

37. Pollard, D.D.; Aydin, A. Progress in understanding jointing over the past century. GSA Bull. 1988, 100, 1181-1204. [CrossRef]

38. Cooke, M.L.; Underwood, C.A. Fracture termination and step-over at bedding interfaces due to frictional slip and interface opening. J. Struct. Geol. 2001, 23, 223-238. [CrossRef]

39. Heng, S.; Liu, X.; Li, X.Z.; Zhang, X.D.; Yang, C.H. Experimental and numerical study on the non-planar propagation of hydraulic fractures in shale. J. Pet. Sci. Eng. 2019, 179, 410-426. [CrossRef]

40. Fu, W.; Ames, B.C.; Bunger, A.P.; Savitski, A.A. Impact of Partially Cemented and Non-persistent Natural Fractures on Hydraulic Fracture Propagation. Rock Mech. Rock Eng. 2016, 49, 4519-4526. [CrossRef]

41. Cheng, W.; Jin, Y.; Chen, M.A.; Xu, T.; Zhang, Y.K.; Diao, C. A criterion for identifying hydraulic fractures crossing natural fractures in 3D space. Pet. Explor. Dev. 2014, 41, 371-376. [CrossRef]

42. Gale, J.F.W.; Elliott, S.J.; Laubach, S.E. Hydraulic Fractures in Core From Stimulated Reservoirs: Core Fracture Description of HFTS Slant Core, Midland Basin, West Texas. In Proceedings of the Unconventional Resources Technology Conference, Houston, Texas, USA, 23-25 July 2018; p. 18. 
43. Maity, D.; Ciezobka, J. Using microseismic frequency-magnitude distributions from hydraulic fracturing as an incremental tool for fracture completion diagnostics. J. Pet. Sci. Eng. 2019, 176, 1135-1151. [CrossRef]

44. Harris, D.O.; Bell, R.L.J.E.M. The measurement and significance of energy in acoustic-emission testing. Exp. Mech. 1977, 17, 347-353. [CrossRef]

45. Zhou, D.W.; Zhang, G.Q.; Wang, Y.Y.; Xing, Y.K. Experimental investigation on fracture propagation modes in supercritical carbon dioxide fracturing using acoustic emission monitoring. Int. J. Rock Mech. Min. Sci. 2018, 110, 111-119. [CrossRef]

46. Guo, T.; Zhang, S.; Qu, Z.; Zhou, T.; Xiao, Y.; Gao, J. Experimental study of hydraulic fracturing for shale by stimulated reservoir volume. Fuel 2014, 128, 373-380. [CrossRef]

47. Urbancic, T.I.; Maxwell, S.C. Microseismic Imaging of Fracture Behavior in Naturally Fractured Reservoirs. In Proceedings of the SPE/ISRM Rock Mechanics Conference, Irving, TX, USA, 20-23 October 2002; p. 7.

(C) 2019 by the authors. Licensee MDPI, Basel, Switzerland. This article is an open access article distributed under the terms and conditions of the Creative Commons Attribution (CC BY) license (http://creativecommons.org/licenses/by/4.0/). 